Homepage: http://epubs.icar.org.in/ejournal/index.php/JWR

\title{
Growth, productivity and nutrient uptake of barley (Hordeum vulgare) as influenced by different varieties and clipping management
}

\author{
Balwinder Singh Dhillon* and RS Uppal \\ Punjab Agricultural University, Ludhiana 141 004, Punjab, India
}

\section{Article history}

Received: 28 June, 2018

Revised : 01 August, 2018

Accepted: 04 August, 2018

\section{Citation}

Dhillon BS and RS Uppal 2018. Growth, productivity and nutrient uptake of barley (Hordeum vulgare) as influenced by different varieties and clipping management. Wheat and Barley Research $10(2): 89-92$. doi.org/ 10.25174/22494065/2018/81019

\section{*Corresponding author}

Email: balwinderdhillon.pau@gmail.com

(C) Society for Advancement of Wheat and Barley Research

\begin{abstract}
A field experiment was conducted at research farm of Punjab Agricultural University, Ludhiana during winter ( $r a b i$ ) seasons of 201516 and 2016-17 to study the effect of different varieties and clipping management on growth, productivity and nutrient uptake of barley (Hordeum vulgare L.). Variety DWRUB 52 produced significantly higher dry-matter, tiller count, grain yield, straw yield and nutrients uptake (N, P, K and Zn) than PL 807 and PL 426, while plant height of this variety was statistically similar with PL 807 . Zn foliar spray at anthesis and early milk stage with clipping increased the plant height and dry matter of crop, while clipping alone reduced these growth parameters. Grain yield of control crop was statistically similar with both clipping stages viz. at 50 and 60 DAS. However, there was an increase of $5.7 \%$ in the grain yield when clipping was done at 50 DAS over no clipping. Clipping at 50 and $60 \mathrm{DAS}$ along with $\mathrm{Zn}$ application brought about 13.1 and $8.5 \%$ increased the grain yield over control crop. Zn foliar application significantly increased the nitrogen, phosphorous, potassium and zinc nutrients uptake by grain and straw of barley crop than control.
\end{abstract}

Keywords: Barley, clipping management, grain yield, nutrient uptake, Zn spray

\section{Introduction}

Barley (Hordeum vulgare L.) is a fast growing, cool season, annual grain crop, that could be used as forage as well as, cover crop to improve soil fertility and it is the fourth most important cereal crop of the world after wheat, rice and maize. Its grains contain 8 to $10 \%$ protein and $74 \%$ carbohydrates besides the minerals and vitamin B-complex and thus forms a staple food, cattle feed, malt for manufacturing of beer and other liquor products (Singh et al., 2009). Its straw is also used for making hay and silage. A variety of any crop having good yield potential, resistance to insect-pest and disease sometimes becomes susceptible to such biotic factor and thus loses the yield potential. Clipping an annual plant at progressively later stages of growth would also be expected to decrease total production and especially grain yield. However, clipping affects the plant height, growth and productivity depending on the stage of crop at the time of clipping. Clipping at tillering stage, did not impede regrowth of barley under semi-arid conditions (El-Shatnawi et al.,
1999). Micronutrient malnutrition is a global health problem affecting more than 3 billion people worldwide (Cakmak et al., 2010). About 44\% children under five years of age are zinc $(\mathrm{Zn})$ deficient in India (Kapil and Jain, 2011). About 66 and 85\% women and children are anemic in Punjab and India, respectively (Singh, 2009). Deficiency of $\mathrm{Zn}$ cause serious human health complications such as infections, impaired brain functions, poor mental development, weak babies and anaemia (Fraga, 2005). Low dietary-intake is the main cause of microelement deficiencies in humans (Cakmak et al., 2010). $\mathrm{Zn}$ is also essential in human body as a co-factor for more than 200 enzymatic reactions which are vital for growth, development, immune function and resistance to infections (Fischers and Black, 2004). In a global study initiated by FAO, it was shown that about $30 \%$ of the cultivated soils of the world are $\mathrm{Zn}$ deficient. It is estimated that $\mathrm{Zn}$ deficiency is the most widespread micronutrient deficiency in cereals. Foliar spraying of different nutrients 
make them readily absorbed by plant leaves and are not lost through fixation, decomposition and leaching. The positive effect of spraying zinc on growth and yield of different crops has been reported by several investigators. So, present study was devised with the objective to study the impact of clippings on growth, productivity and uptake of barley varieties through $\mathrm{Zn}$ biofortification.

\section{Materials and methods}

A field experiment was conducted at research farm of Punjab Agricultural University, Ludhiana, Punjab on loamy sand soil during winter (rabi) season of 2015-16 and 2016-17. The soil of experimental site had a $\mathrm{pH}$ of 7.4 and 7.3, containing 0.37 and $0.39 \%$ organic carbon, 179.2 and $192.8 \mathrm{~kg} / \mathrm{ha}$ available $\mathrm{N}, 28.5$ and $31.3 \mathrm{~kg} / \mathrm{ha}$ available $\mathrm{P}$ and 143.9 and $137.1 \mathrm{~kg} / \mathrm{ha}$ available K during growing season of 2015-16 and 2016-17, respectively. Total rainfall received during crop season was 80.4 and $100.3 \mathrm{~mm}$ during growing season of 2015-16 and 2016-17, respectively. The experiment comprised of 15 treatments was laid out in split plot design with four replications having three varieties, viz. DWRUB 52, PL 807 and PL 426 were taken in main plot. Five clipping management practices, viz. control, clipping at 50 and 60 DAS without $\mathrm{Zn}$ spray and with $0.5 \% \mathrm{Zn}$ foliar application at anthesis and early milk stage were taken as sub plot treatments (Table 1). Recommended dose of nutrients to barley was applied as $62.5 \mathrm{~kg} \mathrm{~N} / \mathrm{ha}, 30 \mathrm{~kg} \mathrm{P}_{2} \mathrm{O}_{5}$ and $15 \mathrm{~kg} \mathrm{~K} \mathrm{~K}_{2} \mathrm{O}$ through urea $(46.4 \% \mathrm{~N})$, single super phosphate $(16 \%$ $\left.\mathrm{P}_{2} \mathrm{O}_{5}\right)$ and muriate of potash $\left(60 \% \mathrm{~K}_{2} \mathrm{O}\right)$, respectively at the time of sowing. The site was a under sunhemp-wheat (Triticum aestivum L.) cropping system for 3 years before the establishment of the experiment. Crop was sown at $5 \mathrm{~cm}$ depth with a seed drill at row spacings of $22.5 \mathrm{~cm}$ on November 17 and October 25 during crop season of 2015-16 and 2016-17, respectively. Crop was sown by a uniform seed rate of $87.5 \mathrm{~kg} / \mathrm{ha}$. Clipping was taken with hedge trimmer as per treatments by $10-15 \mathrm{~cm}$ and leaving plant for further regeneration. The harvesting of crop was done on 7th April, 2016 and 31st March, 2017. Ten random plants were selected from each plot, excluding the border row, for taking observation on plant height. Representative plant samples at 120 days after sowing (DAS) from $25 \mathrm{~cm}$-row length in penultimate rows were oven dried to record dry weight. The number of tiller $/ \mathrm{m}$ row length at $120 \mathrm{DAS}$ at marked spots in penultimate rows of each plot was counted and converted into tillers/ $\mathrm{m} 2$. The grain and straw yield of net plot was converted into tonnes/ha. Grain and straw sample were collected at harvest and were dried, processed and examined for $\mathrm{N}$, $\mathrm{P}, \mathrm{K}$ and $\mathrm{Zn}$ uptake.

\section{Results and discussion}

\section{Growth attributes}

The growth attributes, viz. plant height, dry matter accumulation and number of tillers were significantly affected due to varieties. PL 807 being at par with DWRUB 52 proved superior to PL 426 for plant height (Table 1) and probably attributed to their genetic constitution. These findings are in line with the results of

Table 1. Crop growth and grain and straw yield and grain straw ratio of barley as influenced by different varieties and clipping management (data pooled over 2 years).

\begin{tabular}{|c|c|c|c|c|c|}
\hline Treatment & $\begin{array}{l}\text { Plant height } \\
(\mathrm{cm})\end{array}$ & $\underset{(\mathrm{t} / \mathrm{ha})}{\text { Dry-matter }}$ & $\begin{array}{l}\text { Tiller count } \\
(\text { no/m2) }\end{array}$ & $\underset{(\mathrm{t} / \mathrm{ha})}{\text { Grain yield }}$ & $\begin{array}{c}\text { Straw yield } \\
(\mathrm{t} / \mathrm{ha})\end{array}$ \\
\hline \multicolumn{6}{|l|}{ Varieties } \\
\hline DWRUB 52 & 93.2 & 11.1 & 349.9 & 3.97 & 8.2 \\
\hline PL 807 & 94.1 & 10.4 & 338.1 & 3.77 & 7.79 \\
\hline PL 426 & 89.5 & 9.5 & 324.5 & 3.25 & 7.35 \\
\hline $\mathrm{SEm} \pm$ & 1.41 & 0.46 & 7.34 & 0.21 & 0.25 \\
\hline $\mathrm{CD}(\mathrm{P}=0.05)$ & 1.3 & 0.2 & 6.9 & 0.12 & 0.21 \\
\hline \multicolumn{6}{|l|}{ Clipping management } \\
\hline Control & 94.5 & 10.06 & 337.7 & 3.51 & 7.63 \\
\hline Clipping at $50 \mathrm{DAS}$ & 92.2 & 10.24 & 340.8 & 3.71 & 7.72 \\
\hline Clipping at $60 \mathrm{DAS}$ & 89.9 & 9.72 & 333.9 & 3.32 & 7.47 \\
\hline Clipping at $50 \mathrm{DAS}+\mathrm{Zn}(\mathrm{s})$ & 93.3 & 10.97 & 340.7 & 3.97 & 8.14 \\
\hline Clipping at $60 \mathrm{DAS}+\mathrm{Zn}(\mathrm{s})$ & 91.5 & 10.67 & 334.4 & 3.81 & 7.94 \\
\hline SEm \pm & 0.78 & 0.22 & 1.48 & 0.11 & 0.12 \\
\hline $\mathrm{CD}(\mathrm{P}=0.05)$ & 1.2 & 0.2 & 4.1 & 0.21 & 0.23 \\
\hline
\end{tabular}

$\mathrm{Zn}(\mathrm{s})=0.5 \% \mathrm{ZnSO} 4$ foliar spray at anthesis and early milk stage 
Sardana and Zhang (2005). DWRUB 52 variety registered significantly higher dry matter accumulation and number of tillers than PL 807 and PL 426. Varietal differences for dry matter accumulation have been reported by Karwasra et al. (1998) and Sardana and Zhang (2005).

Under clipping management, unclipped control crop produced the highest plant height which was significantly higher than clipping at 50 and $60 \mathrm{DAS}$ and clipping at 60 $\mathrm{DAS}+\mathrm{Zn}(\mathrm{s})$ and was at par with clipping at $50 \mathrm{DAS}+\mathrm{Zn}$ (s). Lower plant height under clippings treatments might be attributed to removing vegetation by clipping reduced plant height. The increase in plant height in clipping at 50 $\mathrm{DAS}+\mathrm{Zn}(\mathrm{s})$ and clipping at $60 \mathrm{DAS}+\mathrm{Zn}(\mathrm{s})$ treatments is might be attributed to the physiological role of $\mathrm{Zn}$ in plant metabolism and growth. These results confirms the findings of Day et al. (1968). Dry matter accumulation was significantly higher with $\mathrm{Zn}$ foliar application under clipping at 50 DAS. Whereas, tiller number of control, clipping at $50 \mathrm{DAS}$ and clipping at $50 \mathrm{DAS}+\mathrm{Zn}(\mathrm{s})$ were statistically at par with each other. Similar results were obtained earlier by Pandey et al. (2001).

\section{Grain and straw yield}

Variety DWRUB 52 recorded significantly higher grain and straw yield than PL 807 and PL 426 (Table 1). Variety PL 426 produced significantly lower grain and straw yield than both the varieties viz. PL 807 and DWRUB 52. Variety DWRUB 52 produced 5.3 and $22.1 \%$ higher grain yield than PL 807 and PL 426, respectively. Reduction in the grain yield of PL 426 was attributed to lower leaf area index.

The highest grain yield was recorded in clipping at 50 DAS + Zn (s) which was statistically at par with clipping at $60 \mathrm{DAS}+\mathrm{Zn}(\mathrm{s})$ and significantly higher than other treatments. Clipping increased the grain yield with $\mathrm{Zn}$ foliar spray at $50(13.1 \%)$ and $60(8.5 \%)$ DAS than control crop. Grain yield of control crop was statistically at par with both clipping stages i.e. at 50 and 60 DAS. Grain yield was higher in clipping at 50 DAS than control (Table 1). There was significant effect of foliar application of $\mathrm{Zn}$ with both clipping stages i.e. at 50 and 60 DAS on grain yield of crop. Clipping at $50 \mathrm{DAS}+\mathrm{Zn}$ (s) recorded the highest straw yield which was statistically at par with clipping at $60 \mathrm{DAS}+\mathrm{Zn}$ (s) and significantly higher than other treatments. These results are in conformity with those of Narwal et al. (2010), Kutman et al. (2010), Shi et al. (2010) and Jan et al. (2013).

\section{Nutrients uptake}

Nutrients uptake (N, P, K and Zn) by barley (grain and straw) was significantly affected by different barley varieties and clipping management (Table 2). Variety DWRUB 52 recorded significantly highest nutrients uptake (N, P, K and Zn) which is due to higher grain yield and straw produced by this variety. $\mathrm{Zn}$ foliar application significantly increased the nutrients uptake by grain

Table 2. Nutrients uptake (N, P, K and Zn) by grain and straw as influenced by different varieties and clipping management (data pooled over 2 years).

\begin{tabular}{lcccccccc}
\hline \multirow{2}{*}{ Treatment } & \multicolumn{2}{c}{ Nitrogen $(\mathrm{kg} / \mathrm{ha})$} & Phosphorus $(\mathrm{kg} / \mathrm{ha})$ & Potassium $(\mathrm{kg} / \mathrm{ha})$ & \multicolumn{2}{c}{ Zinc $(\mathrm{g} / \mathrm{ha})$} \\
\cline { 2 - 8 } & Grain & Straw & Grain & Straw & Grain & Straw & Grain & Straw \\
\hline Varieties & & & & & & & & \\
DWRUB 52 & 79.5 & 47.3 & 14.2 & 11.1 & 22 & 72.3 & 197 & 212.9 \\
PL 807 & 71.4 & 42.3 & 12.8 & 10.1 & 19.9 & 66.1 & 176.2 & 184.6 \\
PL 426 & 58.5 & 37.3 & 10.3 & 8.8 & 17 & 61.4 & 149.2 & 165.8 \\
SEm \pm & 6.11 & 2.89 & 1.14 & 0.67 & 1.45 & 3.15 & 13.8 & 13.6 \\
CD (P=0.05) & 3.4 & 1.3 & 0.6 & 0.5 & 0.9 & 2.3 & 8.6 & 6.8 \\
Clipping management & & & & & & & & \\
Control & 67.4 & 41.5 & 11.9 & 9.8 & 18.8 & 65.1 & 149.9 & 147.4 \\
Clipping at 50 DAS & 68.1 & 41.5 & 12.2 & 9.7 & 19.4 & 65.3 & 162.6 & 161.7 \\
Clipping at 60 DAS & 60.6 & 39.6 & 11 & 9.3 & 17.4 & 62.5 & 156.8 & 176.6 \\
Clipping at 50 DAS + Zn (s) & 78.7 & 45.1 & 13.8 & 10.7 & 21.7 & 71.1 & 201.3 & 223.5 \\
Clipping at 60 DAS + Zn (s) & 74.3 & 43.7 & 13.2 & 10.4 & 20.8 & 68.8 & 200.1 & 229.7 \\
SEm \pm & 3.1 & 0.96 & 0.49 & 0.25 & 0.75 & 1.51 & 11 & 16.5 \\
CD (P = 0.05) & 4 & 1.1 & 0.7 & 0.3 & 1.1 & 1.8 & 10 & 9.2 \\
\hline Zn (s) = 0.5\% ZnSO4 foliar spray at anthesis and early milk stage & & & &
\end{tabular}


and straw of barley. Significantly higher nitrogen and potassium uptake in straw was observed in clipping at $50 \mathrm{DAS}+\mathrm{Zn}(\mathrm{s})$ than other clipping treatments. While nitrogen, phosphorus, potassium and zinc uptake by straw and phosphorus and zinc uptake by grain of treatment clipping at $50 \mathrm{DAS}+\mathrm{Zn}(\mathrm{s})$ and clipping at $60 \mathrm{DAS}+\mathrm{Zn}$ (s) were statistically similar.

Thus it is concluded that variety DWRUB 52 gave significantly higher grain yield, straw yield and nutrients uptake. Clipping at 50 DAS improved the growth, productivity and nutrients uptake compared to clipping at 60 DAS, while $\mathrm{Zn}$ foliar application at anthesis and early milk stage improved productivity

\section{References}

1. Cakmak I, WH Pfeiffer and B McClafferty. 2010. Biofortification of durum wheat with zinc and iron. Cereal Chemistry 87:10-20.

2. Day AD, RK Thompson and WF McCaughey. 1968. Effects of clipping on the performance of spring barley (Hordeum vulgare L. emend Law) seeded in October. Agronomy Journal 60:11-12.

3. El-Shatnawi MKJ, HZ Ghosheh, HK Shannag and KI Ereifej.1999. Defoliation time and intensity of wall barley in the Mediterranean Rangeland. Journal of Range Management 52:258-262.

4. Fischer WC and RE Black. 2004. Zinc and the risk for infectious disease. Annual Review of Nutrition 24:255-275.

5. Fraga CG. 2005. Relevance, essentiality and toxicity of trace elements in human health molecular aspects. Molecular Aspects of Medicine 26:235-244.

6. Jan A, M Wasim and A Jr. 2013. Interactive effects of zinc and nitrogen application on wheat growth and grain yield. Journal of Plant Nutrition 36: 1506-20.
7. Kapil U and KJain. 2011. Magnitude of zinc deficiency amongst under five children in India. Indian Journal of Pediatrics 78:1069-1072.

8. Karwasra RS, SN Gupta and RS Kadian. 1998. Response of barley varieties to nitrogen under rainfed condition of Rohtak. Crop Research 15:31-33.

9. Kutman UB, B Yildiz, I Oturk and I Cakmak. 2010. Biofortfication of durum wheat with zinc through soil and foliar application of nitrogen. Cereal Chemistry 87:1-9.

10. Narwal RP, RS Malik and RR Dahiya. 2010. Addressing variations in a few nutritionally important micronutrients in wheat crop. Proceedings $19^{\text {h }}$ World Congress Soil Science. Published on DVD. 1-6 August, Brisbane, Australia.

11. Pandey N, M Gupta and CP Sharma. 2001. Zinc efficiency affects pollen structure and viability of green gram (Vigna radiata L. cv T-44). Geophytolology 28:31-34.

12. Sardana V and G P Zhang. 2005. Effect of time of nitrogen application on the growth and yield of two barley (Hordeum vulgare L.) cultivars. Cereal Research Communication 33: 255-257.

13. Shi R, Y Jhang, X Chan, Q Sun, F Zhang, V Romheld and C Zou. 2010. Influence of long-term nitrogen fertilization on micronutrient density in grains of winter wheat (Triticum aestivum L.). Journal of Cereal Science 51: 165-170.

14. Singh MV. 2009. Micronutrient nutritional problems in soils of India and improvement for human and animal and human health. Indian Journal of Fertilisers 5:11-16.

15. Singh RP. HP Tripathi and AS Yadav. 2009. Effect of storage of cutting and nitrogen levels on grain and fodder yield of barley. Indian Journal of Agricultural Sciences 79:78-79. 